\title{
Application of a New Portable Microscopic Somatic Cell Counter with Disposable Plastic Chip for Milk Analysis
}

\author{
J. S. Moon, ${ }^{\star 1}$ H. C. Koo, $\ddagger^{1}$ Y. S. Joo, ${ }^{\star}$ S. H. Jeon,§ D. S. Hur,§ C. I. Chung,§ H. S. Jo,§ and Y. H. Park $\ddagger^{2}$ \\ *Department of Bacteriology, National Veterinary Research and Quarantine Service, Anyang, Gyeonggi-do, Republic of Korea \\ †KRF Zoonotic Disease Priority Research Institute, and \\ łDepartment of Microbiology, College of Veterinary Medicine and the BK21 program for Veterinary Science, Seoul National University, \\ Seoul, Republic of Korea \\ §Digital Bio Technology Co. Ltd., Seoul, Republic of Korea
}

ABSTRACT

The somatic cell count (SCC) is one of the international standards for monitoring milk quality, and it is a useful indicator of mastitis. The current reference method for determining the SCC in raw milk is direct microscopic analysis, but this method requires welltrained staff to maintain its accuracy and reproducibility. To overcome these inconveniences, we developed a portable system (the C-reader system) that utilizes the capillary flow of a microfluidic chamber by surface modification of the hydrophilicity. The microfluidic technology of disposable microchips allows for low consumption of reagents, and a combination of ready-to-use reagents makes the daily work easier. The repeatability test of the C-reader using 10 composite bovine milk samples satisfied the recommended values for SCC equipment. In addition, an acceptable accuracy level of the natural logarithmic-transformed SCC $[\ln (\mathrm{SCC} / 1,000): \pm 0.059$ to 0.112] was achieved using composite raw milk samples and various somatic cell standard solutions from the American Eastern Laboratory and the Korean National Veterinary Research and Quarantine Service. After testing 875 composite milk samples, the C-reader showed a high correlation coefficient $\left(\mathrm{R}^{2}=0.935\right.$ to 0.964 ) and a low mean difference value in log-transformed SCC (-0.088 to 0.004) compared with 3 automatic commercialized somatic cell counters (Fossomatic 4000, Somacount 150, and Somascope). In conclusion, the C-reader system is a new, easy-to-use automatic on-farm method with acceptable repeatability and accuracy for measuring SCC in large dairies and smaller laboratories.

Key words: bovine raw milk, somatic cell count, Creader, disposable plastic microchip

Received October 5, 2006.

Accepted January 5, 2007.

${ }^{1}$ These authors contributed equally to this study.

${ }^{2}$ Corresponding author: yhp@snu.ac.kr

\section{INTRODUCTION}

The measurement of SCC has become one of the most reliable indicators for determining milk quality and the price of raw milk within the dairy industry (Schukken et al., 1992; Ott and Novak, 2001; Jayarao et al., 2004). Several methods such as the direct microscopic somatic cell counting (DMSCC) method, electronic particle counting method, and fluoro-optic electronic cell counting method by disk cytometry or flow cytometry have been used to determine the SCC. Among them, DMSCC with methylene blue staining is the reference method for making a direct estimation of the cells, but this method is slow and requires trained staff (Forest and Small, 1959). In addition, the lack of specificity between the cells and cytoplasmic particles, as well as the time and labor requirements are negative aspects of DMSCC (International Dairy Federation, 1995a).

The Coulter counter (Coulter Electronics Ltd., Luton, Bedfordshire, UK), which is based on electronic particle counting, is a high-speed device for particle size analysis that involves adding a formaldehyde solution to the milk to be examined to fix the somatic cells, and eliminating fat particles by treatment with a lysing solution with an overlapping size range of the cells (Miller et al., 1986; International Dairy Federation 1995a). The other automatic instruments to measure SCC indirectly are the Fossomatic 90, based on disk cytometry, and the Fossomatic 5000 (Foss Electric, Hillerød, Denmark), Somacount 150 (Bentley Instruments Inc., Chaska, $\mathrm{MN}$ ), and Somascope (Delta Instruments, Drachten, the Netherlands) based on the flow cytometry method (FCM). The FCM-based instruments have been used more frequently than the Coulter counter at DHI organizations because somatic cells can be counted in raw or preserved milk after heating without the need for additional treatment.

The principle of FCM methods is that a suspension of cells is stained and forced through a capillary tube that is illuminated in front of a microscope objective. Every passing cell is then registered by photo-electron- 
ics attached to the microscope. Therefore, the FCM is an accurate and reliable instrumental method that can be used to quantify SCC in milk very quickly and at low cost. A good correlation between the FCM method and the reference method, DMSCC, was reported in raw milk samples $(R=0.88)$ at concentrations ranging from $10^{3}$ to $10^{6}$ cells $/ \mathrm{mL}$ (Gunasekera et al., 2003). In addition, the cell count measured by FCM showed good agreement $(R=0.98)$ with the SCC data obtained using the standard Fossomatic method based on disk cytometry (Gunasekera et al., 2003). The fluoro-optic electronic cell counting methods, however, should be calibrated regularly using standard solutions that have been confirmed by DMSCC for quality control (Schmidt-Madsen, 1975; International Dairy Federation, 1995a).

The California Mastitis Test is a very simple and widely used cow-side test of the milk quality in mastitis control efforts at a dairy farm, but it cannot be used for counting the correct SCC, which is the absolute factor for determining the price of milk, because of its low sensitivity and specificity (Schalm and Noorlander, 1957; Schalm et al., 1971; Sargeant et al., 2001). The DeLaval cell counter (DeLaval, Tumba, Sweden) is a new analytic portable instrument for counting somatic cells optically and automatically within $1 \mathrm{~min}$, but this method has a high coefficient of variation $(\mathbf{C V})$; that is, low repeatability (Nelson, 2004). In this study, an automatic system (C-reader) that is fully compatible with the DMSCC was developed. In this study, the repeatability and accuracy of the portable C-reader system was evaluated by comparing its SCC data in raw milk and somatic cell standard solutions with those from DMSCC. In addition, the SCC data in raw milk samples were compared between the C-reader and 3 major conventional instruments (Fossomatic 4000, Somacount 150, and Somascope) because these 3 machines are popular in large dairies and small laboratories worldwide, including in Korea.

\section{MATERIALS AND METHODS}

\section{Setup of C-Reader System}

The C-reader system comprises disposable plastic microchips, staining solutions, a fluorescence microscopic instrument, an image analysis program operated on a PC, and an LCD monitor with a touch screen and function key, which are built in a single machine weighing only $17 \mathrm{~kg}$ (Figure 1). A charge-coupled device (CCD) camera captures the fluorescence images of the somatic cells, and the image software analyzes and counts the number of cells automatically.

Optical System of the C-Reader. The disposable plastic chip is mounted on an inverted microscope-type optical system of the C-reader (Digital Bio Technology
Co., Seoul, Korea). A green laser at $532 \mathrm{~nm}$ and a UV or white light-emitting diode (LED) is used as light source. The image of the sample within the chip is scanned by a CCD camera with the fast stage moving the chip in the $\mathrm{X}-\mathrm{Y}$ direction. The fluorescence is collected by a $4 \times$ objective and passed through a filter block $(600 \pm 25 \mathrm{~nm})$ and to the CCD camera (Mintron, Taiwan). For accurate counting of the cell number, 90 frames of fluorescence images homogeneously distributed through the count area are processed in a single sample. In addition, images of the cell morphology can be observed using the white LED light. The C-reader system is interfaced with a PC by a serial communication cable and a frame-grabber board. Visual C++-based software is used to operate the cell number counting result display, cell size histogram, and live images.

Disposable Plastic Microchips. The microfluidic technique was used to design the disposable plastic microchip, which evenly distributes the cell density throughout the channel and generates a natural capillary flow for sample loading. The microfluidic channel is located in the center of these chips, which was developed for a more accurate counting of the cell number as follows: $4 \mathrm{~mm}$ wide, $50 \mathrm{~mm}$ long ( $52 \mathrm{~mm}$ for the total channel including the sample injection part), and 0.1 $\mathrm{mm}$ high. Accordingly, the loading volume of a disposable plastic chip is $20 \mu \mathrm{L}\left(4 \times 50 \times 0.1 \mathrm{~mm}^{3}\right)$ and the total analysis volume of the channel area is $8 \mu \mathrm{L}$, considering the capture of 90 frames of the cell image (an analysis volume of approximately $0.089 \mu \mathrm{L}$ per frame), which is 80 times larger than the animal cell counting area of a manual hemocytometer (Freshney, 1993).

The disposable plastic chips are fabricated from polymethyl methacrylate using a microinjection molding process developed by Digital Bio Technology. A backward step structure is used at the outlet of the channel to achieve an even distribution and rapid precipitation of cells. The internal surface of the plates is chemically treated with gas plasma to alter its wetness, resulting in the generation of a natural capillary flow (Anders and Helene, 2002). Two plates are bonded to build the closed channel structure, one being optically clear and smooth, and the other being an open microchanneled. The bonding chemicals have no accompanying reactions with aqueous liquids, cells, or any other materials used in biological tests, which allows them to accomplish passive flow velocity control in the plastic microchannel chips.

Staining Solutions. The staining solutions $(0.1 \mathrm{M}$ PBS solution, $\mathrm{pH}$ 5.8) including the detergent Triton$\mathrm{X} 100(0.2 \%)$ for cell lysis and fluorescent dye $(0.025$ $\mathrm{mg} / \mathrm{mL}$ of ethidium bromide; Sigma, St. Louis, MO) are used for staining the somatic cells. The detergents break the cell membrane so that the fluorescent dye 
A.

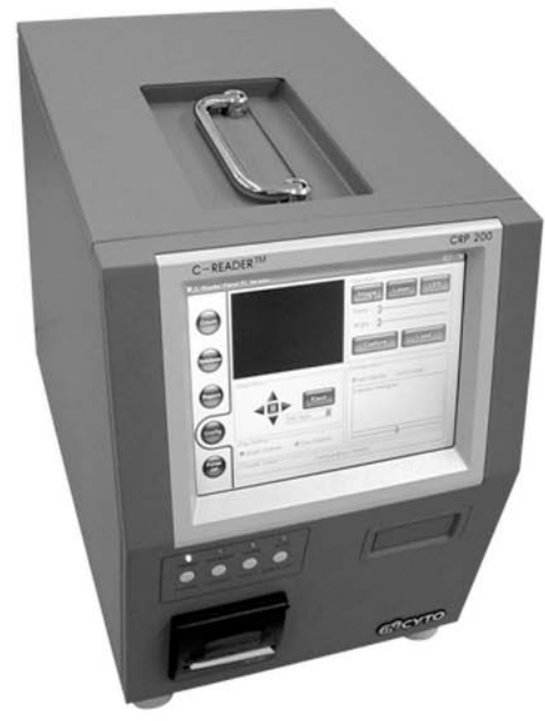

B.
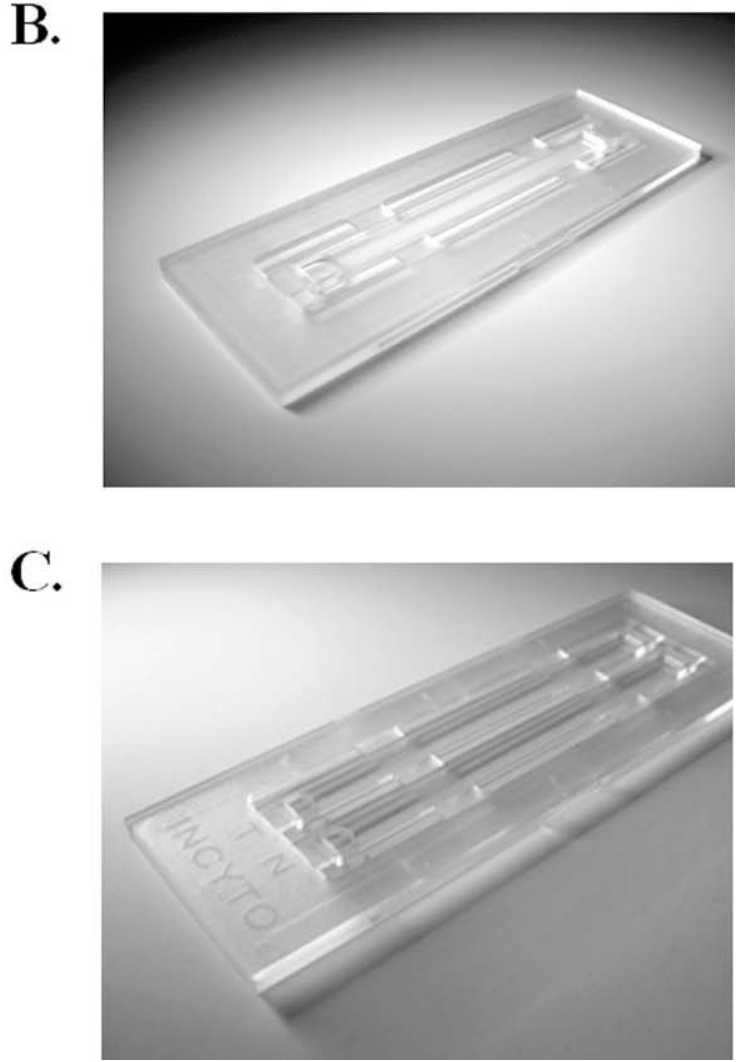

Figure 1. Portable C-reader with a cell analysis system (A). The system weighs $17 \mathrm{~kg}$; dimensions are 260 (width) $\times 385($ depth $) \times 330$ (height) mm. Disposable plastic chips: single (B) and 2-channel (C) chips with capacity for loading 1 or 2 samples, respectively.

can penetrate the cell membrane and stain the DNA or RNA of the cell. Ethidium bromide, which has excitation and emission wavelengths of $510 \mathrm{~nm}$ (green light) and $590 \mathrm{~nm}$ (red light), respectively, was used as the fluorescent dye in the staining solution (Crary and Borysenko, 1986).

\section{Analysis of SCC in Milk}

Preparation of Raw Milk and Standard Somatic Cell Solutions. The composite raw milk samples were collected at random from dairy farms located in Gyeonggi province, Korea, from July to September 2004. A pilot study showed that the SCC in the 5 raw milk samples within the range of cell counts of $10^{5}$ to $10^{6}$ cells $/ \mathrm{mL}$ were similar regardless of whether a preservation treatment had been used. Therefore, 961 composite raw milk samples with a density ranging from $6.0 \times 10^{3}$ to $1.0 \times 10^{6}$ cells $/ \mathrm{mL}$ were treated with the preservation reagent, potassium dichromate $\left(\mathrm{K}_{2} \mathrm{Cr}_{2} \mathrm{O}_{7}\right.$, Sigma), to help stabilize the somatic cells (International Dairy Federation, 1995b).

To test the accuracy of the C-reader cell analysis system, various somatic cell standard solutions were prepared using 12 samples with cell counts ranging from $1.7 \times 10^{5}$ to $9.9 \times 10^{5}$ cells $/ \mathrm{mL}$ from the American Eastern Laboratory (Fairlawn, $\mathrm{OH}$ ), and 3 types of solutions with different SCC (low, medium, and high) from the Korean National Veterinary Research and Quarantine Service (NVRQS). Each standard somatic cell solution verified by DMSCC was used to evaluate the accuracy of the C-reader system according to the guidelines of a standardizing somatic cell counting system.

Analysis of SCC by C-Reader and DMSCC. At least $100 \mu \mathrm{L}$ of the composite bovine milk sample or standard solution was mixed with the same amount of somatic cell staining solution. Twenty microliters of the mixed sample was loaded into the disposable plastic chip. Within $1 \mathrm{~min}$, the total cell number in $8 \mu \mathrm{L}$ of stained raw milk or standard solution was measured using the C-reader. The reader analyzes the total fluorescent particles automatically according to the principle of DMSCC and ensures the accuracy of the cell counting. The final number of somatic cells was calculated using the following formulation:

$$
\text { number of somatic cells } / \mathrm{mL}=(\mathrm{A} / \mathrm{B}) \times \mathrm{N} \times 1,000 \text {, }
$$


where $\mathrm{A}$ is the average number of somatic cells measured in 90 images, B is $0.089 \mu \mathrm{L}$, which is the analysis volume per image, and $\mathrm{N}$ is the dilution factor in which raw milk samples or standard solutions are mixed with the same amount of a somatic cell staining solution.

For DMSCC, dried milk smears were stained using 1 of 3 Levowitz-Weber stains, a Canadian modification of the modified Newman-Lampert stain for microscopic counting (Levowitz, 1957; Embert, 1986; Packard et al., 1992).

To measure the repeatability of the C-reader, $10 \mathrm{com}$ posite bovine milk samples were tested with different ranges of somatic cells (from $1.4 \times 10^{4}$ to $1.0 \times 10^{6} / \mathrm{mL}$ ), which was repeated 10 times. Before testing using the C-reader, the selection of raw milk samples containing various numbers of somatic cells was performed by measuring the approximate concentrations of the cells in raw milk using the Fossomatic 4000 instrument. Seventy-six milk samples (ranging from $1.0 \times 10^{5}$ to 1.0 $\times 10^{6}$ cells $/ \mathrm{mL}$ ) and 2 types of somatic cell standard solutions, whose densities ranged from $1.7 \times 10^{5}$ to 9.9 $\times 10^{5}$ cell $\mathrm{s} / \mathrm{mL}$ (verified by DMSCC), were also applied to evaluate the accuracy and calculate the standard deviations of the repeatability of the C-reader system. The determination of the SCC by the C-reader and DMSCC was performed 5 times, and the comparison of the SCC data was analyzed by GLM (for mean comparison) and REG (for differences of regression) procedures of SAS (SAS Institute, 1992). In addition, the SCC in the composite raw milk samples $\left(\mathrm{n}=28,6.0 \times 10^{4}\right.$ to $1.0 \times 10^{6}$ ) with and without a preheat treatment at $40^{\circ} \mathrm{C}$ were determined by the C-reader and compared as described above to analyze whether the heating treatment affected the SCC measured by the C-reader.

Automated Instruments for SCC. To compare the C-reader system with other indirect conventional instruments (Fossomatic 4000, Somacount 150, and Somascope), a total of 875 composite bovine raw milk samples with a different range of somatic cells $(6.0 \times$ $10^{3}$ to $1.0 \times 10^{6}$ ) were tested in duplicate with (for examination by 3 conventional instruments) or without (for C-reader system) a preheat treatment of $15 \mathrm{~min}$ at $40^{\circ} \mathrm{C}$ according to the protocols provided by the manufacturer of each instrument.

\section{Statistical Analysis}

For the analysis of the SCC variable, a natural logarithmic transformation of the SCC [SCCt $=\ln (\mathrm{SCC} /$ $1,000)]$ was performed to approximate the normal distribution as suggested by De Vliegher et al. (2004). To determine the repeatability of the C-reader, which is a measure of the variation between the replicate determination in a single instrument using the same samples,
Table 1. Analysis of the repeatability of the C-reader cell counting method using composite raw milk samples with different somatic cell counts

\begin{tabular}{lccc}
\hline & \multicolumn{2}{c}{ SCC $(\times 1,000 / \mathrm{mL})$} & \\
\cline { 2 - 3 } $\begin{array}{l}\text { Sample } \\
\text { no. }\end{array}$ & $\begin{array}{c}\text { Mean } \\
\text { (10 replicates })\end{array}$ & SD & $\begin{array}{c}\text { Coefficient } \\
\text { of variation } \\
(\%)\end{array}$ \\
\hline 1 & 14 & 0.950 & 7.017 \\
2 & 37 & 0.839 & 2.263 \\
3 & 55 & 2.671 & 4.825 \\
4 & 102 & 1.472 & 1.444 \\
5 & 133 & 1.101 & 0.822 \\
6 & 182 & 2.121 & 1.169 \\
7 & 250 & 2.669 & 1.069 \\
8 & 436 & 3.853 & 0.883 \\
9 & 641 & 3.736 & 0.583 \\
10 & 1,022 & 11.353 & 1.111 \\
\hline
\end{tabular}

the analysis of SCC in 10 milk samples was performed 10 times, from which the CV were calculated. The accuracy, which is a measure of the bias between the reference method and the C-reader, was determined by analyzing the agreement (means comparison, standard deviations of repeatability, and regression analysis) between the SCC obtained with the reference test (DMSCC) and C-reader using the GLM and REG procedures of SAS (SAS Institute, 1992) according to the International Dairy Federation (IDF) standard 128A (IDF, 1999; Gonzalo et al., 2004). The mean comparison and regression analysis of the SCC between the Creader and 3 automatic instruments in commercial use (Fossomatic 4000, Somacount 150, and Somascope) was also performed.

\section{RESULTS AND DISCUSSION}

\section{Repeatability of the C-Reader System}

Table 1 shows the overall repeatability data obtained from the C-reader system. The $\mathrm{CV}$ values, which represent the repeatability of the C-reader, decreased with an increasing number of cells and were $<5 \%$ in almost all the somatic cell ranges, but $7 \%$ at $1.4 \times 10^{4}$ cells/ $\mathrm{mL}$. This satisfies the IDF recommendations for somatic counters, which are 5 to $10 \%$ at $1 \times 10^{5}$ to $2 \times$ $10^{5}$ cells $/ \mathrm{mL}$, and 4 to $5 \%$ at $4 \times 10^{5}$ to $5 \times 10^{5}$ cells/ $\mathrm{mL}$ (IDF, 1995a). The acceptable standard deviation of repeatability $\left(\mathbf{S}_{\mathbf{r}}, 0.005\right.$ to 0.009$)$ for the SCCt in the raw milk samples and standard somatic cell solution from the American Eastern Laboratory and Korean NVRQS was calculated and the results are shown in Table 2. Both low CV and $\mathrm{S}_{\mathrm{r}}$ values represent greater repeatability of the C-reader system determined in bovine milk than the DMSCC (Schmidt-Madsen, 1975).

A digital camera in the DeLaval cell counter takes 2 images of the nuclei of the somatic cells stained by a 
Table 2. Evaluation of accuracy and repeatability of the C-reader system in measuring SCC using different samples $^{1}$

\begin{tabular}{lccc}
\hline & \multicolumn{3}{c}{ Sample } \\
\cline { 2 - 4 } Values & $\mathrm{A}$ & $\mathrm{B}$ & $\mathrm{C}$ \\
\hline No. of samples & 76 & 12 & 9 \\
Mean of $\mathrm{x}, \mathrm{y}^{2}$ & $5.534,5.522$ & $6.070,6.060$ & $6.058,6.049$ \\
Mean of difference (D) & 0.012 & 0.010 & 0.009 \\
Intercept (a) & -0.003 & 0.084 & 0.087 \\
Slope of the regression line (b) & 0.999 & 0.984 & 0.984 \\
Accuracy (SCCt $\left.{ }^{2} / \mathrm{mL}\right)$ & \pm 0.112 & \pm 0.104 & \pm 0.059 \\
Observed t value $\left(\mathrm{t}_{\text {obs }}\right)$ & 1.181 & 0.773 & 1.151 \\
Reference t value & 1.995 & 2.201 & 2.306 \\
Degree of repeatability, $\mathrm{S}_{\mathrm{r}}$ value & 0.005 & 0.009 & 0.006 \\
\hline
\end{tabular}

\footnotetext{
${ }^{1}$ Samples: $\mathrm{A}=$ raw milk samples; $\mathrm{B}=12$ types of American Eastern Laboratory's standard somatic cell solutions; and $\mathrm{C}=$ standard solutions from the Korean National Veterinary Research Quarantine Service (Gyeonggi-do, Korea).

${ }^{2}$ The $\mathrm{x}$ and $\mathrm{y}$ values indicate the mean of the natural logarithmic transformed SCC [SCCt $=\ln (\mathrm{SCC} /$ 1,000)] obtained by the C-reader system and by the direct microscopic method, respectively.
}

DNA-specific fluorescent reagent within the cassette and counts the cell nuclei one by one (Nelson, 2004). It was reported that the DeLaval cell counter makes an incorrect estimation of the SCC at the $2 \times 10^{5}$ cells/ $\mathrm{mL}$ level in $4 \%$ of cases compared with the Fossomatic instrument, and has CV values of 12,8 , and $7 \%$ at $1 \times$ $10^{5}, 4 \times 10^{5}$, and $1 \times 10^{6}$ cells $/ \mathrm{mL}$, respectively (Nelson, 2004). This is higher than that recommended by the IDF for somatic counters (IDF, 1995a). The C-reader instrument, whose CCD camera processes 90 frames of fluorescent images for a single sample, however, can reduce the high CV value (low repeatability) of the DeLaval cell counter, which might be due to taking only 2 pictures of nuclei per sample.

\section{Comparison of SCC Measured by the C-Reader System and DMSCC}

Using the DMSCC method, the nucleus of the somatic cells is shown as dark blue or blue in the microscopic image (Figure 2A), whereas the C-reader system analyzes the somatic cells as ethidium bromide-stained fluorescent particles (Figure 2B). When the statistical significance of the differences between the DMSCC and C-reader results for those parameters was analyzed by the value of $t$ observed $\left(t_{o b s}\right)$ under the hypotheses (mean of the difference in SCCt $=0.00$; slope of regression line $=1.00$; intercept $=0.00$ ), there was no significant difference in the SCCt obtained by the C-reader and DMSCC with the lower $t_{\text {obs }}$ values compared with the reference $t$ values in the composite raw milk samples or the standard somatic cell solutions (Table 2).

An acceptable level of accuracy of \pm 0.059 to 0.112 SCCt $[\ln (\mathrm{SCC} / 1,000)] / \mathrm{mL}$ was achieved using the Creader system compared with the reference method (DMSCC; $P<0.01$ ). The high linear correlation coeffi- cient values were obtained between the SCCt in the 2 types of standard solutions $\left(\mathrm{R}^{2}=0.994\right.$ to $0.996 ; P<$ $0.01)$ as well as raw milk $\left(\mathrm{R}^{2}=0.992 ; P<0.01\right)$ measured by DMSCC and the C-reader. The C-reader system is based on the principles of the DMSCC method; however, the C-reader system avoids the negative influences of the experimenter through automation of instruments and the use of disposable plastic chips. It requires only a premixing procedure of raw milk and staining solution by the analyst.

\section{Comparison of the C-Reader System with Other Conventional Automatic Instruments}

When analyzing the SCC using conventional fluorooptical electronic cell counting methods (Fossomatic 4000 , Somacount 150, and Somascope), a pretreatment step of raw milk (heating for $15 \mathrm{~min}$ at $40^{\circ} \mathrm{C}$ ) was needed to allow the staining of DNA with the fluorescent dye (Miller et al., 1986; Hinz et al., 1992; Paape et al., 2001). When the SCC in the raw milk samples measured by the C-reader with and without a preheat treatment at $40^{\circ} \mathrm{C}$, however, were compared using the GLM procedure of SAS (SAS Institute, 1992), there was no significant difference in the SCC observed between the 2 groups.

When the results of the C-reader were compared with 3 other commercialized automatic methods based on indirect FCM by linear regression analysis, the Creader system was found to have a high linear correlation coefficient $\left(\mathrm{R}^{2}\right)$ of 0.964 [95\% confidence interval (CI), 0.980 to 0.984 ] with the Fossomatic 4000; an $\mathrm{R}^{2}$ of 0.935 (95\% CI, 0.962 to 0.971 ) with the Somacount 150; and an $\mathrm{R}^{2}$ of 0.960 (95\% CI, 0.977 to 0.982 ) with the Somascope. With the high correlation, the SCCt data from each type of conventional equipment showed 
A.

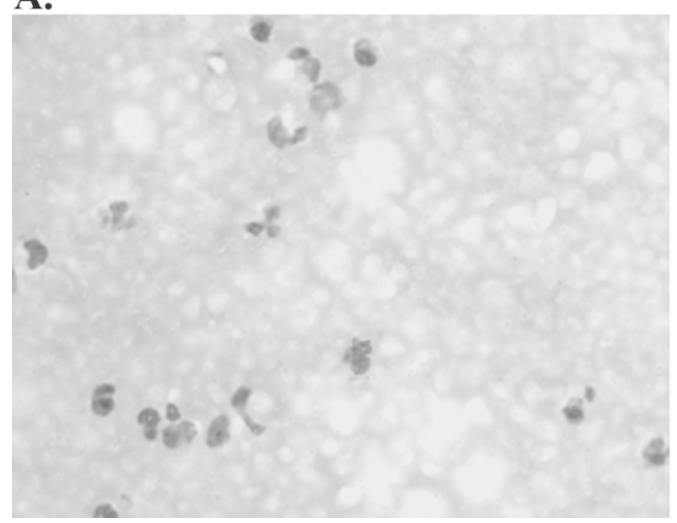

B.

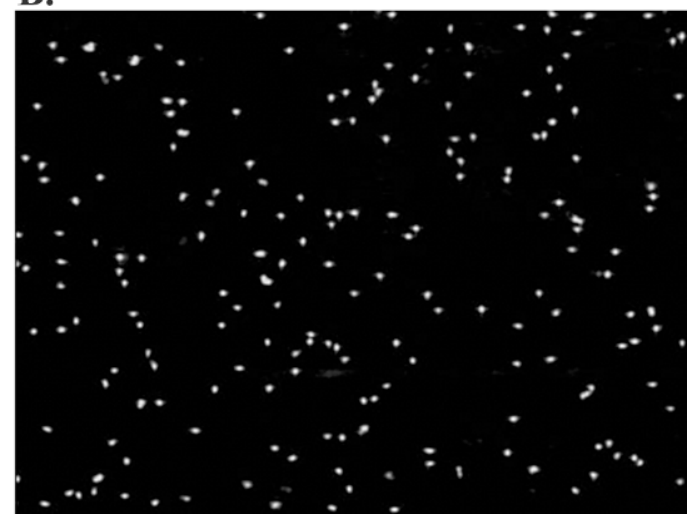

Figure 2. Image comparison of the direct microscopic somatic cell counts (DMSCC) and C-reader when $\mathrm{SCC}$ is $4.77 \times 10^{6}$ cells $/ \mathrm{mL}$ : A) Stained somatic cell image with methylene blue (DMSCC, $\times 1,000$ ) and B) fluorescent image of stained somatic cells captured by the Creader system.

a linear relationship with those from the C-reader $(P$ $<0.01$ ). In addition, a low mean difference in the SCCt (D, -0.088 to 0.004 ) between the C-reader and the other conventional automatic instruments was calculated. The high $\mathrm{R}^{2}$ and low $\mathrm{D}$ values indicate that the $\mathrm{C}$-reader can be used as a reliable instrument for SCC analysis.

The maintenance of the C-reader instrument requires neither tubing nor washing system as a result of the use of disposable plastic chips and a separate staining solution, which makes the C-reader system more suitable for small laboratories with an inexpensive automated SCC test. In addition, it is suitable for use as an on-farm tool because of its ease of use, low cost of the instrument, low reagent consumption, use of a touch screen and function keys, and portability. The single machine system weighs only $17 \mathrm{~kg}$ including the PC and LCD monitor, with a ready-to-use type in under a minute. Although the C-reader instrument is more expensive and complex than the California Mastitis Test for monitoring the SCC level of quarter milk at a dairy farm, it can be used as accurate method for the daily measurements of the SCC in raw milk from cows or bulk tanks at dairy farms. Moreover, the Creader can provide the farmer with a means of achieving economic profitability through an increase in the premiums paid by milk purchasing cooperatives if the milk from high SCC cows is not sold.

In conclusion, the portable C-reader is an easy-to-use automatic system for measuring SCC, without the need for calibration and heating the milk samples, in large dairies and smaller laboratories. This method has greater or comparable repeatability and accuracy compared with the manual DMSCC method and other expensive automatic instruments.

\section{ACKNOWLEDGMENTS}

This study was funded by Digital Bio Technology Co. Ltd. (Seoul, Korea) as well as the National Veterinary Research and Quarantine Service (Gyeonggi-do, Korea). H. C. Koo and Y. H. Park were supported by the Korean Research Foundation Grant (KRF-2006-005J02903), Research Institute of Veterinary Science, Department of Veterinary Microbiology, College of Veterinary Medicine, and the BK21 Program for Veterinary Science, Seoul National University. The authors thank G. C. Jang from NVRQS; S. Shin, Y. K. Park, and S. Y. Hwang from College of Veterinary Medicine, Seoul National University; and S. Y. Gang from Dang Jin Dairy Livestock Cooperative Federation for their technical assistance in many ways.

\section{REFERENCES}

Anders, L., and D. Helene. 2002. Stability of polycarbonate and polystyrene surfaces after hydrophilization with high intensity oxygen RF plasma. J. Colloid Interf. Sci. 246:214-221.

Crary, B., and M. Borysenko. 1986. Rapid counting of cultured plasma cells using ethidium bromide as a fluorescent counter-stain. Biotechniques 4:98-101.

De Vliegher, S., H. W. Barkema, H. Stryhn, G. Opsomer, and A. De Kruif. 2004. Impact of early lactation somatic cell count in heifers on somatic cell counts over the first lactation. J. Dairy Sci. 87:3672-3682.

Embert, H. 1986. Erythrocyctes. Pages 34-39 in Veterinary Clinical Pathology. 4th ed. W. B. Saunders, Philadelphia, PA.

Forest, H. L., and E. Small. 1959. The direct microscopic clump count as a measure of quality of non-fat dry milk. 15th Proc. Int. Dairy Congr. 3:1883-1889.

Freshney, R. I. 1993. Culture of animal cells: A manual of basic technique. 3rd ed. Wiley-Liss, New York, NY.

Gonzalo, C., J. C. Boixo, J. A. Carriedo, and F. San Primitivo. 2004. Evaluation of rapid somatic cell counters under different analytical conditions in ovine milk. J. Dairy Sci. 87:3623-3628.

Gunasekera, T. S., D. A. Veal, and P. V. Attfield. 2003. Potential for broad applications of flow cytometry and fluorescence technique 
in microbiological and somatic cell analyses of milk. Int. J. Food Microbiol. 85:269-279.

Hinz, C. W., G. L. Hein, L. S. Hinckey, J. Althaus, and H. Bengsch. 1992. Methods to detect abnormal milk. Pages 334-338 in Standard Methods for the Examination of Dairy Products. 16th ed. R. T. Marshall, ed. American Public Health Association, Washington, DC.

International Dairy Federation (IDF). 1995a. Enumeration of somatic cells. FIL-IDF Standard no. 148A. IDF, Brussels, Belgium.

International Dairy Federation (IDF). 1995b. Milk payment systems for ex-farm milk. FIL-IDF Standard no. 305. IDF, Brussels, Belgium.

International Dairy Federation (IDF). 1999. Definition and evaluation of the overall accuracy of indirect methods of milk analysis application to calibration procedure and quality control in the dairy laboratory. FIL-IDF Standard no. 128A. IDF, Brussels, Belgium.

Jayarao, B. M., S. R. Pillai, A. A. Sawant, D. R. Wolfgang, and N. V. Hegde. 2004. Guideline for monitoring bulk tank milk somatic cell and bacterial counts. J. Dairy Sci. 87:3561-3573.

Levowitz, D. 1957. An inquiry into the usefulness of the standard methods, direct microscopic count. J. Milk Food Technol. 20:288-293.

Miller, R. H., M. J. Paape, and J. C. Action. 1986. Comparison of milk somatic cell counts by Coulter and Fossomatic counters. J. Dairy Sci. 69:1942-1946.

Nelson, Y. 2004. Tre metoder för diagnos av mastit i fält. Dept. Obstetrics and Gynaecology, SLU. Examensarbete / Sveriges lantbruksuniversitet, Veterinärmedicinska fakulteten, Veterinärpro- grammet vol. 50:1-18. http://ex-epsilon.slu.se/archive/00000066/ Accessed Jan. 14, 2006.

Ott, S. L., and P. R. Novak. 2001. Association of herd productivity and bulk tank somatic cell counts in U.S. dairy herds in 1996. J. Am. Vet. Med. Assoc. 218:1325-1330.

Paape, M. J., B. Poutrel, A. Contreras, J. C. Marco, and A. V. Capuco. 2001. Milk somatic cells and lactation in small ruminants. J. Dairy Sci. 84(E Suppl.):E237-E244.

Packard, J., V. S. Tatini, R. Fugua, J. Heady, and C. Gilman. 1992. Direct microscopic methods for bacteria or somatic cells. Pages 309-321 in Methods for the Examination of Dairy Products. 16th ed. R. T. Marshall, ed. American Public Health Association, Washington, DC.

Sargeant, J. M., K. E. Leslie, J. E. Shirley, B. J. Pulkrabek, and G. H. Lim. 2001. Sensitivity and specificity of somatic cell count and California Mastitis Test for identifying intramammary infection in early lactation. J. Dairy Sci. 84:2018-2024.

SAS Institute. 1992. SAS/STAT User's Guide. Version 6, 10th ed. SAS Institute, Inc., Cary, NC.

Schalm, O. W., E. J. Carroll, and N. C. Jain. 1971. Bovine Mastitis. Lea and Febiger, Philadelphia, PA.

Schalm, O. W., and D. O. Noorlander. 1957. Experiments and observations leading to development of the California mastitis test. J. Am. Vet. Med. Assoc. 130:199-204.

Schmidt-Madsen, P. 1975. Fluoro-optic electronic cell-counting on milk. J. Dairy Res. 42:227-239.

Schukken, Y. H., K. E. Leslie, A. J. Weersink, and S. W. Martin. 1992. Ontario bulk-milk somatic cell count reduction program. 2. Dynamics of bulk-milk somatic cell counts. J. Dairy Sci. 75:3359-3366. 